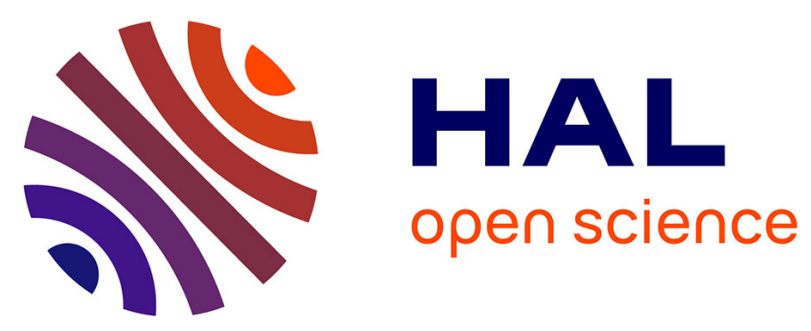

\title{
Difluoroboron complexes of functionalized dehydroacetic acid: electrochemical and luminescent properties
}

Samira Baaziz, Nathalie Bellec, Yann Le Gal, Rachedine Kaoua, Franck Camerel, Saleha Bakhta, Bellara Nedjar-Kolli, Thierry Roisnel, Vincent Dorcet, Olivier Jeannin, et al.

\section{To cite this version:}

Samira Baaziz, Nathalie Bellec, Yann Le Gal, Rachedine Kaoua, Franck Camerel, et al.. Difluoroboron complexes of functionalized dehydroacetic acid: electrochemical and luminescent properties. Tetrahedron, 2016, 72 (4), pp.464-471. 10.1016/j.tet.2015.11.034 . hal-01254803

HAL Id: hal-01254803

https://hal-univ-rennes1.archives-ouvertes.fr/hal-01254803

Submitted on 24 Mar 2016

HAL is a multi-disciplinary open access archive for the deposit and dissemination of scientific research documents, whether they are published or not. The documents may come from teaching and research institutions in France or abroad, or from public or private research centers.
L'archive ouverte pluridisciplinaire HAL, est destinée au dépôt et à la diffusion de documents scientifiques de niveau recherche, publiés ou non, émanant des établissements d'enseignement et de recherche français ou étrangers, des laboratoires publics ou privés. 


\section{Graphical abstract}

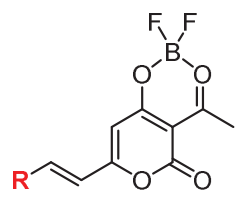<smiles></smiles><smiles>CCOc1cc(C)oc(=O)c1C</smiles>

$\mathrm{R}=\mathrm{Me}_{3} \mathrm{TTF}$,

ferrocenyl, phenyl

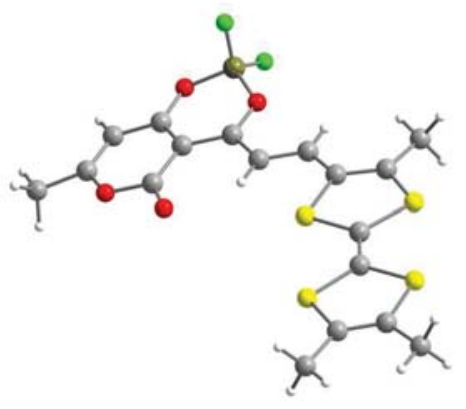




\title{
Difluoroboron complexes of functionalized dehydroacetic acid: electrochemical and luminescent properties
}

Samira Baaziz, ${ }^{\mathrm{a}, \mathrm{b}}$ Nathalie Bellec, ${ }^{\mathrm{a}, *}$ Yann Le Gal, ${ }^{\mathrm{a}}$ Rachedine Kaoua, ${ }^{\mathrm{a}, \mathrm{b}, \mathrm{c}}$ Franck Camerel, ${ }^{\mathrm{a}}$ Saleha Bakhta, ${ }^{\mathrm{a}, \mathrm{b}}$ Bellara Nedjar-Kolli, ${ }^{\mathrm{b}}$ Thierry Roisnel, ${ }^{\mathrm{a}}$ Vincent Dorcet, ${ }^{\mathrm{a}}$ Olivier Jeannin, ${ }^{\mathrm{a}}$ Dominique Lorcy ${ }^{\mathrm{a}}$

a Institut des Sciences Chimiques de Rennes (ISCR), UMR 6226 CNRS-Université de Rennes 1, Campus de Beaulieu, 263 avenue du Général Leclerc, Bat 10A, 35042 Rennes Cedex, France

b Laboratoire de Chimie Organique et Appliquée, Université des Sciences et de la Technologie Houari Boumediene (USTHB), 16111 Alger, Algeria

${ }^{\mathrm{c}}$ Institut des Sciences, Université Mohamed Akli Ouelhadj, 10000, Bouira, Algeria

*Corresponding author. Fax: +33 2232367 38; e-mail address: nathalie.bellec@univ-rennes1.fr (N. Bellec).

\begin{abstract}
A series of dehydroacetic acid difluoroboron complexes functionalized by a phenyl ring or an electroactive core (tetrathiafulvalene or ferrocene) were synthesized and characterized. The redox properties of these derivatives have been analyzed by cyclic voltammetry and the molecular structures of some of the difluorobon complexes are presented and discussed. The photophysical properties of selected difluoroboron complexes were determined in solution and in the solid state evidencing an AIEE (Aggregation Induced Enhancement Emission) phenomenon.
\end{abstract}

\section{Keywords}

Dehydroacetic acid, Tetrathiafulvalene, Ferrocene, Boron difluoride complex

\section{Introduction}

Dehydroacetic acid (DHA) has mainly been investigated as precursor of various heterocyclic compounds of potential biological interest. ${ }^{1}$ In addition due to its planar 
structure, its reactivity and also its ability to act as a chelating ligand, this synthon could be used as a coordinating part in precursor of molecular materials based on tetrathiafulvalene (TTF) for example. ${ }^{2}$ Indeed, DHA and the Schiff base of DHA exhibit similar binding sites as the well-known acetylacetonate group (acac) and thus can complex numerous metallic ions. ${ }^{3,4}$ Besides metallic ions, DHA and its Schiff base can also complex difluoroboron moiety (Chart 1). The formation of such difluoroboron complexes present two advantages: (i) it enhances the reactivity of DHA itself and (ii) some of these derivatives can exhibit fluorescence properties. $^{5}$<smiles>CC1=C(C)c2c(cc(C)oc2=O)OB(F)O1</smiles>

$\mathrm{DHA}^{-\mathrm{BF}_{2}}$<smiles>[R]N1B(F)Oc2cc(C)oc(=O)c2C1C</smiles>

Schiff base of $\mathrm{DHA}-\mathrm{BF}_{2}$<smiles></smiles>

acac-BF 2

\section{Chart 1}

Our current interest in the synthesis of various electroactive ligands containing the TTF core for the elaboration of molecular materials, ${ }^{6}$ prompted us to investigate the possibility to graft, on the DHA, this electroactive moiety. The $\mathrm{TTF}^{7}$ is not the only electrophore which exhibits easily accessible and reversible oxidation processes, indeed the ferrocene (Fc) ${ }^{8}$ is also easily oxidized to the ferrocenium ion. We reported the synthesis of a TTF functionalized by a $\mathrm{DHA}-\mathrm{BF}_{2}$ moiety where the fluorophore and the electrophore were connected thanks to the reaction of TTF-hydrazone with DHA. ${ }^{9}$

Herein we investigated the synthesis of $\mathrm{DHA}-\mathrm{BF}_{2}$ and Schiff base of $\mathrm{DHA}-\mathrm{BF}_{2}$ functionalized either by an electrophore, the TTF and the Fc, or by a phenyl group in order to analyse the influence of the electrophore on the fluorophore properties. For that purpose, three approaches were used: i) Wittig reaction at the 6 position involving the aldehydes bearing an 
electroactive unit and a phosphonium salt of DHA, ii) condensation reactions of these aldehydes with $\mathrm{DHA}-\mathrm{BF}_{2}$ at the acetyl position and iii) condensation of the aldehydes on the DHA- hydrazone. Three different aldehydes were used, two with an electroactive unit (Fc and TTF) and one which could serve as a reference: benzaldehyde. Depending on the reaction used, the spacer group between the DHA moiety and the electroactive part will be different as well as the position of the connecting part on the DHA core (Chart 2).

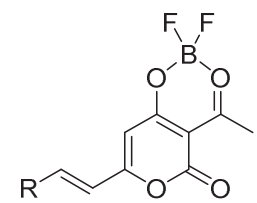

3

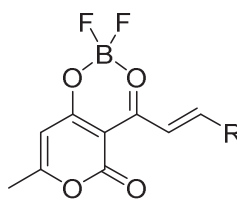

$\mathrm{R}=\mathrm{TTF}, \mathrm{Fc}, \mathrm{C}_{6} \mathrm{H}_{5}$

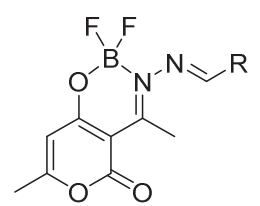

9

\section{Chart 2}

\section{Results and discussion}

Wittig olefination starting from triphenylphosphonium salt $\mathbf{1}$ enabled us to introduce the electroactive moiety on the methyl group at the 6 position of DHA. ${ }^{10}$ The addition of two equivalents of sodium methoxide to salt $\mathbf{1}$ generates the corresponding ylide which reacts with ferrocenecarboxaldehyde (Fc-CHO), trimethyltetrathiafulvalene carboxaldehyde ( $\mathrm{Me}_{3} \mathrm{TTF}-$ CHO) and benzaldehyde to afford compounds $\mathbf{2 a}$, $\mathbf{2 b}$ and $\mathbf{2} \mathbf{c}^{10}$ in $22 \%, 57 \%$ and $48 \%$ yield respectively (Scheme 1). The addition of an excess of $\mathrm{Et}_{2} \mathrm{O}_{2} \mathrm{BF}_{3}$ to a toluene solution of 2a-c under inert atmosphere afforded the corresponding difluoroboron complexes 3a-c in very good yields as colored solids. Purification cannot be performed by column chromatography as a large amount of these complexes 3a-c get stuck on silica. The other part which was eluted correspond to the starting material 2a-c indicating, that upon chromatography, these difluoroboron complexes undergo decomplexation. Moreover, compounds $\mathbf{2 b}$ and $\mathbf{3 b}$ are poorly soluble in usual organic solvents. The ${ }^{1} \mathrm{H}$ NMR spectra of these derivatives 2a-c and 
3a-c exhibit two doublet signals associated with the protons of the formed ethylenic bridge with a coupling constant of $15-17 \mathrm{~Hz}$ which indicate a trans coupling across the double bond. ${ }^{11}$ Disappearance of the hydroxyl signal $(\delta=16.6 \mathrm{ppm})$ confirms the formation of complexes 3.

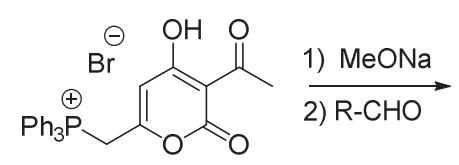

1

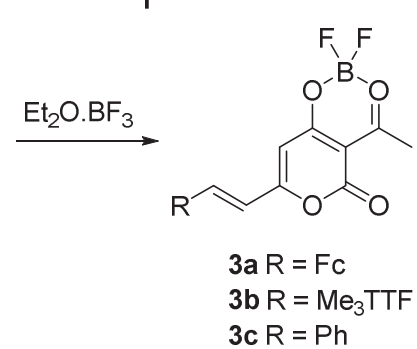

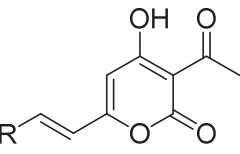

$2 \mathrm{a} R=\mathrm{Fc}$

2b R $=\mathrm{Me}_{3} \mathrm{TTF}$

$2 \mathrm{c} R=\mathrm{Ph}$

\section{Scheme 1.}

The second strategy that we studied in order to graft an electroactive core to a DHAdifluoroboron complex consists in the use of 3-acetyl-6-methyl-2-oxo-2H-pyran-4-yl difluoroborate $\mathbf{4}$ as starting material. Indeed, DHA-difluoroboron complex $\mathbf{4}$ in the presence of various aldehydes in acetic anhydride medium is known to give condensation compound at the acetyl position. ${ }^{12}$ Moreover, compared with DHA itself the reactivity of the methyl group of the acetyl moiety is considerably increased by the presence of the boron difluoride complex. Thus, we prepared the complex $\mathbf{4}$ through the reaction of boron trifluoride diethyl etherate with dehydroacetic acid. ${ }^{12}$ Then by heating the aldehydes, Fc-CHO, $\mathrm{Me}_{3} \mathrm{TTF}-\mathrm{CHO}$ or benzaldehyde with complex $\mathbf{4}$ in acetic anhydride, we formed the targeted complexes $\mathbf{5 a - c}$ as green solids, in $60 \%$ yield for $\mathbf{5 a}$ but in lower yields for $\mathbf{5 b - c ,} 7$ and $12 \%$ respectively (Scheme 2). This difference in the yields can be easily explained by the different work up used to obtain these complexes. Indeed, $\mathbf{5 a}$ precipitated in the medium while for $\mathbf{5 b}$ and $\mathbf{5 c}$ purification by column chromatography was performed and as already mentioned for 3a-c, 
upon purification by column chromatography decomplexation of $\mathbf{5 b}$-c partially occur. On the other hand, it is also possible to form the corresponding uncomplexed derivatives $\mathbf{6 a - b}$ in good yields (64-75\%) through the hydrolysis of $\mathbf{5 a - b}$ in ethanol in the presence of $\mathrm{Na}_{2} \mathrm{CO}_{3} .{ }^{12}$ Here again, analyses of the ${ }^{1} \mathrm{H}$ NMR spectra indicate that the ethylenic bridge formed is under the trans configuration as a typical ${ }^{3} \mathrm{~J}_{\text {trans }}$ coupling constant of $15-16 \mathrm{~Hz}$ is observed. The influence of the electron donating ability of the R group can also be observed on these spectra as the chemical shift observed for these ethylenic protons is downfield for the benzene derivatives compared with the one bearing a Fc or a TTF core.

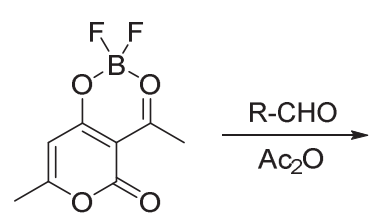

4

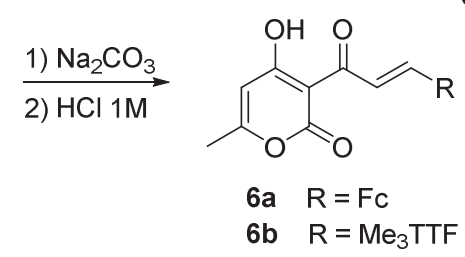

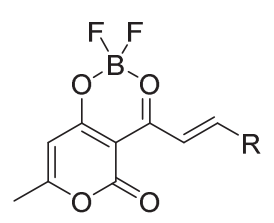

5a $\quad \mathrm{R}=\mathrm{FC}$

5b $\mathrm{R}=\mathrm{Me}_{3} \mathrm{TTF}$

5c $\mathrm{R}=\mathrm{Ph}$

Scheme 2.

Crystals suitable for X-ray diffraction studies have been obtained for compounds $\mathbf{5 a}$ and $\mathbf{5 b}$ by slow concentration of a dichloromethane solution. The molecular structures of $\mathbf{5 a}$ and $\mathbf{5 b}$ are represented in Figure 1 and selected bond lengths and bond angles are collected in Table 1. The DHA-boron moieties in compounds $\mathbf{5 a}$ and $\mathbf{5 b}$ exhibit similar trends: an overall flat geometry with the boron out of the plane with the six-membered difluoroboron ring folded along the $\mathrm{O} \bullet \cdot \mathrm{O}$ axis with an angle of $20.8^{\circ}$ and $17.3^{\circ}$ for complexes $\mathbf{5 a}$ and $\mathbf{5 b}$. Within both structures, the DHA boron moiety is connected to the electroactive part with a $\mathrm{C}=\mathrm{C}$ bond under a trans configuration. The geometry of the TTF in complex $\mathbf{5 b}$ is almost planar as the 
folding angles along the S•..S axis are only 0.04 and $2.82^{\circ}$. The bond lengths of the TTF core are those expected for a neutral TTF (central C=C of 1.346(6) $\AA$ ).
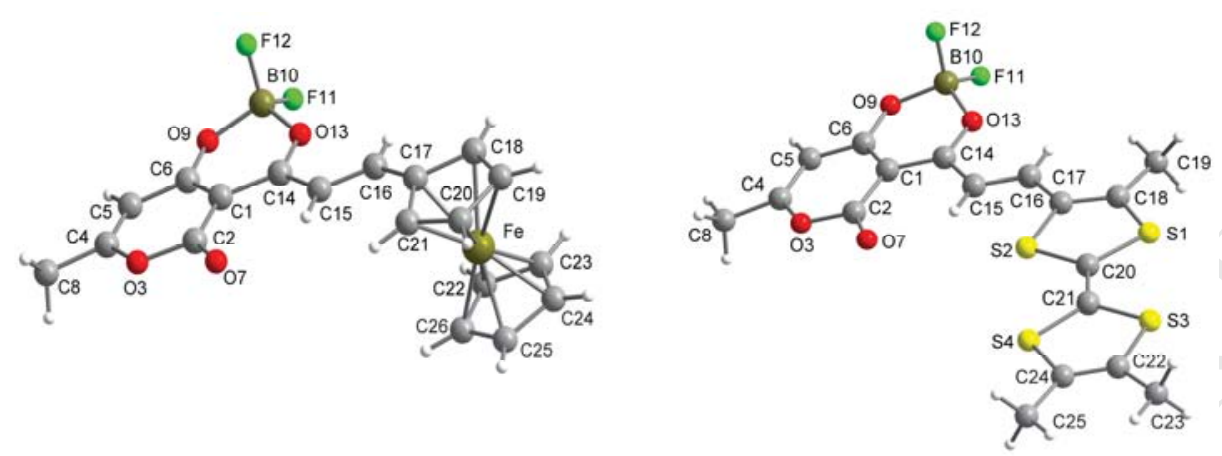

Fig. 1. Molecular structure of 5a (left), 5b (right)

Table 1. Comparison of selected bond lengths in $\AA$ and angles in ${ }^{\circ}$ of the chelate ring in complexes $\mathbf{5 a}$ and $\mathbf{5 b}$.

\begin{tabular}{cccccc}
\hline Bond lengths & $\mathbf{5 a}$ & $\mathbf{5 b}$ & Bond angles & $\mathbf{5 a}$ & $\mathbf{5 b}$ \\
\hline C15-C16 & $1.350(4)$ & $1.352(5)$ & C14-C15-C16 & $122.5(3)$ & $121.4(3)$ \\
C14-C15 & $1.425(3)$ & $1.425(5)$ & O13-C14-O15 & $116.7(2)$ & $117.1(3)$ \\
C14-O13 & $1.304(3)$ & $1.302(4)$ & O13-C14-C1 & $118.7(2)$ & $118.9(3)$ \\
C1-C14 & $1.440(4)$ & $1.421(5)$ & C14-C1-C6 & $118.8(2)$ & $119.2(3)$ \\
C1-C6 & $1.397(3)$ & $1.414(5)$ & C1-C6-O9 & $122.2(2)$ & $121.9(3)$ \\
C6-O9 & $1.305(3)$ & $1.303(4)$ & C6-O9-B10 & $121.2(2)$ & $121.3(3)$ \\
O9-B10 & $1.483(4)$ & $1.503(5)$ & O9-B10-O13 & $110.5(2)$ & $110.6(3)$ \\
B10-O13 & $1.481(3)$ & $1.476(5)$ & B10-O13-C14 & $123.5(2)$ & $124.3(3)$ \\
\hline
\end{tabular}

For the preparation of the target derivatives through the third approach, we prepared DHA-hydrazone 7 according to literature procedure by adding one equivalent of hydrazine monohydrate to an ethanolic solution of DHA. ${ }^{13}$ The condensation reaction occurs immediately and an abundant precipitate appears in the media at room temperature to give the corresponding hydrazone 7. Crystals suitable for an X-ray diffraction study were obtained for 7 and the molecular structure is shown in Fig. 2. DHA-hydrazone 7 exhibits a planar 
geometry with the establishment of intramolecular hydrogen bonding between the $\mathrm{O}-\mathrm{H}$ and the $\mathrm{sp}^{2} \mathrm{~N}$ atom of the hydrazone (1.821(1) $\AA$ ) forming a pseudo six membered cycle.

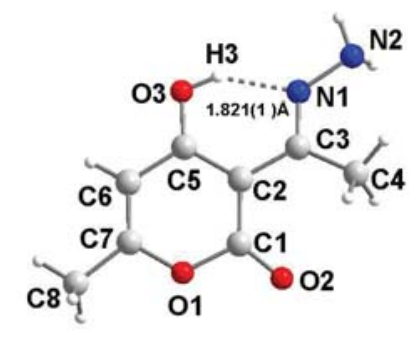

Fig 2. Molecular structure of DHA-hydrazone 7

Reactions were carried out between DHA-hydrazone 7 and the three aldehydes (Fc-CHO, $\mathrm{Me}_{3}$ TTF-CHO and benzaldehyde). These reactions, with the electroactive moieties were performed in THF in the presence of $\mathrm{HCl}$ to afford $\mathbf{8 a}$ and $\mathbf{8 b}$ in $74 \%$ and $53 \%$ yield respectively as dark colored solids (Scheme 3). ${ }^{9}$ The reaction of DHA-hydrazone 7 with benzaldehyde was carried out in refluxing $\mathrm{EtOH}$ and led to the desired derivative $\mathbf{8 c}$ in $75 \%$ yield. In order to prepare the difluoroboron complex of the derivatives 8a-c, we added an excess of $\mathrm{Et}_{2} \mathrm{O} \cdot \mathrm{BF}_{3}$, in the presence of triethylamine, to a solution of 8a-c in dichloromethane under inert atmosphere. The difluoroborane complexes 9a-c were isolated after purification by column chromatography. It is worth noting that in this case decomplexation upon column chromatography was not observed. 


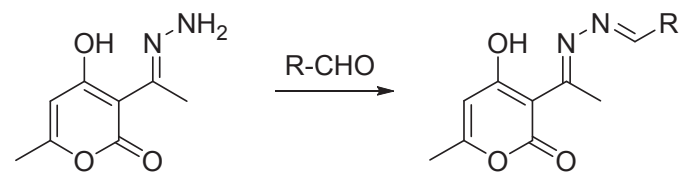<smiles></smiles>

$8 \mathrm{a} R=\mathrm{Fc}$

8b $\mathrm{R}=\mathrm{Me}_{3} \mathrm{TTF}$

8c $\mathrm{R}=\mathrm{Ph}$

$$
\begin{aligned}
& \text { 9a } R=F c \\
& \text { 9b } R=M_{3} T T F \\
& \text { 9c } R=P h
\end{aligned}
$$

\section{Scheme 3.}

Crystals suitable for X-ray diffraction studies have been obtained for compounds 8a and 9a and their molecular structures are represented in Figure 3. Within compound 8a, analysis of the bond lengths of the linker between the DHA and the ferrocene moieties together with the finding of a hydrogen atom on N13, which was introduced in the structural model through Fourier difference maps analysis, indicate that the linker is not an azino structure but a hydrazone one. It is worth noting that for the starting material, DHAhydrazone, the crystal structure determination led to the other tautomer, the imine form. Actually it is known that, imine-enamine tautomerism of pyronic derivatives such as DHA exists. Moreover, depending on the substituent, either the enamine or the imine's form is favored (Scheme 4) ${ }^{14}$ Herein, the enamino ketone form for $\mathbf{8 a}$ is obtained. Intramolecular hydrogen bonding is observed between the $\mathrm{N}-\mathrm{H}$ and the $\mathrm{O}$ atom within this structure leading to a six-membered cycle. Except for the ferrocenyl group the molecule 8a exhibits a planar skeleton.

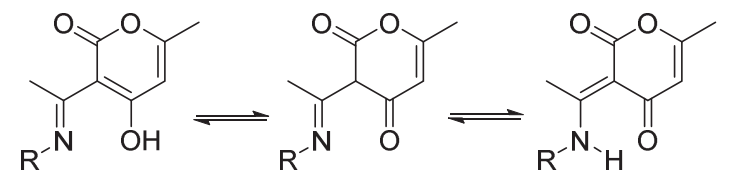

$\beta$-enolimine $\quad \beta$-iminoketone $\quad \beta$-enaminoketone 


\section{Scheme 4.}

Besides the orientation of the ferrocenyl group with regard to the DHA moiety the molecular shape of the difluoroboron complex 9a is very similar to the one of the starting ligand 8a. Indeed the ferrocenyl groups are pointing in opposite direction. Variations can also be noticed on the bond lengths and bond angles mainly on the chelate ring. Selected bond lengths and angles of the chelate rings are collected in Table 2. Within the complex 9a, the C16-C21 bond is shortened compared to ligand 8a (ca.0.05 $\AA$ ) while the C21-O24 bond is lengthened (ca. $0.04 \AA$ ). Due to the presence of the difluoroboron moiety, the bond angles of the chelating moiety are different. Otherwise, in complex 9a, the chelate ring is less distorted than complexes $\mathbf{2 a}$ and $\mathbf{2 b}$ as the torsion angle is only $7.19(24)^{\circ}$.

Table 2. Comparison of selected bond lengths in $\AA$ and angles in ${ }^{\circ}$ of the chelate ring in ligand $8 \mathbf{a}$ and complex $\mathbf{9 a}$.

\begin{tabular}{cccccccc}
\hline Bond lengths & $\mathbf{7}$ & $\mathbf{8 a}$ & $\mathbf{9 a}$ & Bond angles & $\mathbf{7}$ & $\mathbf{8 a}$ & $\mathbf{9 a}$ \\
\hline C11-N12 & & $1.288(2)$ & $1.285(5)$ & C10-C11-N12 & & $122.99(14)$ & $117.1(3)$ \\
N12-N13 & $1.416(2)$ & $1.3918(17)$ & $1.417(4)$ & C11-N12-N13 & & $111.88(12)$ & $117.6(3)$ \\
N13-C14 & $1.312(2)$ & $1.3225(19)$ & $1.331(5)$ & N12-N13-C14 & $122.78(15)$ & $123.40(13)$ & $113.1(3)$ \\
C14-C16 & $1.442(2)$ & $1.432(2)$ & $1.440(5)$ & N13-C14-C16 & $117.71(15)$ & $116.40(13)$ & $117.4(4)$ \\
C16-C21 & $1.444(2)$ & $1.442(2)$ & $1.388(6)$ & C14-C16-C21 & $121.01(14)$ & $121.11(13)$ & $120.1(4)$ \\
C21-O24 & $1.266(2)$ & $1.2645(18)$ & $1.305(4)$ & C16-C21-O24 & $123.14(15)$ & $123.36(13)$ & $123.2(3)$ \\
O24-B25 & & - & $1.465(5)$ & C21-O24-B25 & & - & $124.6(3)$ \\
B25-N13 & & & $1.572(6)$ & O24-B25-N13 & & - & $108.8(3)$ \\
& & & & B25-N13-C14 & & - & $125.1(3)$ \\
\hline
\end{tabular}



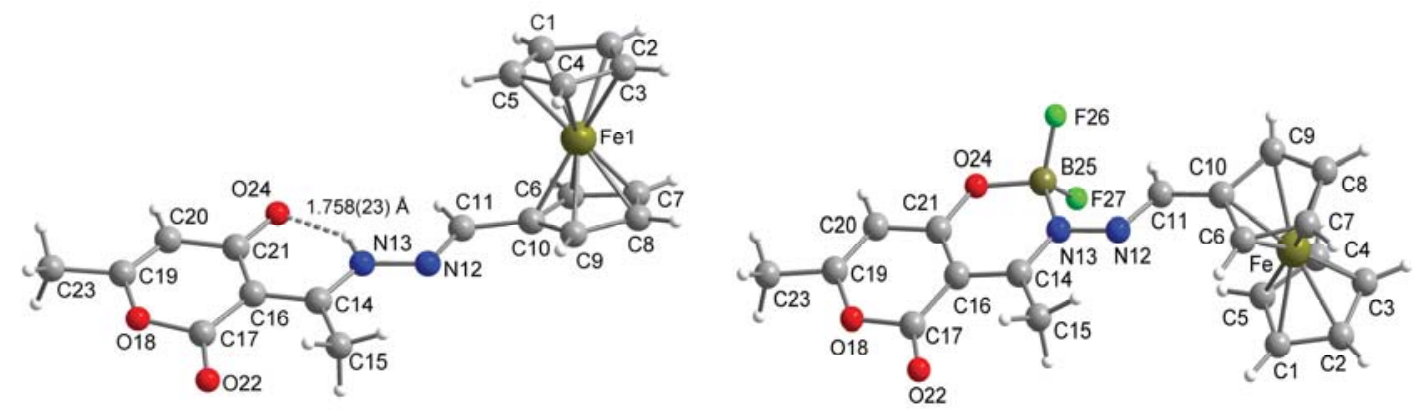

Fig. 3. Molecular structure of $\mathbf{8 a}$ (left) and 9a (right).

In order to study the influence of the complexation on the donating ability of the electroactive moieties, we performed electrochemical investigations on the starting ligands and on the difluoroboron complexes. For all the ferrocene derivatives one reversible monoelectronic wave is observed corresponding to the oxidation of the ferrocene moiety into the ferrocenium species. For all the TTF derivatives, two reversible monoelectronic oxidation waves are observed corresponding to the formation of the radical cation and the dication species respectively. In both series, the TTF and the ferrocene, the presence of the boron complex induces a shift of the oxidation potentials towards more positive potentials indicating the electron withdrawing effect of the complexation with boron difluoride (Table 3). Similar effect has been observed previously on TTF-acetylacetonate complexes of difluoroboron. ${ }^{15}$

Table 3. Redox potentials $\mathrm{E}_{1 / 2}, \mathrm{CH}_{2} \mathrm{Cl}_{2}$, Pt, SCE, TBAPF 6 0.1M, $100 \mathrm{mVs}^{-1}$

\begin{tabular}{cccccc}
\hline Ligands & $\mathbf{E}_{\mathbf{1 / 2}}^{\mathbf{1}}$ & $\mathbf{E}_{\mathbf{1 / 2}}^{\mathbf{2}}$ & Complexes & $\mathbf{E}_{\mathbf{1 / 2}}^{\mathbf{1}}$ & $\mathbf{E}_{\mathbf{1 / 2}}^{\mathbf{2}}$ \\
\hline $\mathbf{2 a}$ & 0.58 & & $\mathbf{3 a}$ & 0.63 & \\
$\mathbf{2 b}$ & 0.37 & 0.85 & $\mathbf{3 b}$ & 0.45 & 0.91 \\
$\mathbf{6 a}$ & 0.61 & & $\mathbf{5 a}$ & 0.74 & \\
$\mathbf{6 b}$ & 0.41 & 0.90 & $\mathbf{5 b}$ & 0.48 & 0.94 \\
$\mathbf{8 a}$ & 0.64 & & $\mathbf{9 a}$ & 0.67 &
\end{tabular}


$\begin{array}{llllll}\mathbf{8 b} & 0.38 & 0.87 & \mathbf{9 b} & 0.43 & 0.94\end{array}$

Absorption and emission spectra of selected compounds have been recorded in dichloromethane solutions and the data are gathered in Table 4. Absorption spectra of compound 4 display a strong absorption band centered at $327 \mathrm{~nm}$ together with a weaker one at $258 \mathrm{~nm}$ (Figure 4). These absorption bands are attributed to $\mathrm{n}-\pi^{*}$ and $\pi-\pi^{*}$ transitions centered on the DHA-BF 2 core. Interestingly, this compound was found to be highly luminescent in solution under irradiation at $327 \mathrm{~nm}$. An emission band centred at $360 \mathrm{~nm}$ extending from $330 \mathrm{~nm}$ to $450 \mathrm{~nm}$ in the visible region has been observed and a high fluorescence quantum yield around $74.5 \%$ has been determined relatively to quinine sulfate. The excitation spectra perfectly match absorption spectra, which is in line with a unique excited state and the weak Stokes' shifts (33 nm) observed is in good agreement with a singlet emitting state.

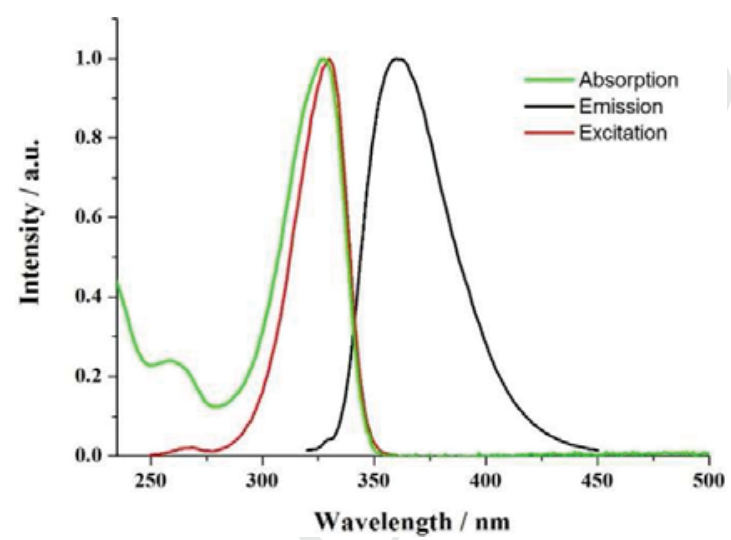

Figure 4. Absorption, emission $\left(\lambda_{\mathrm{ex}}=300 \mathrm{~nm}\right)$ and excitation $\left(\lambda_{\mathrm{em}}=360 \mathrm{~nm}\right)$ of compound 4 in dichloromethane (c $\left.=10^{-5} \mathrm{~mol} . \mathrm{L}^{-1}\right)$.

Table 4. Optical data measured in dichloromethane solution at $298 \mathrm{~K}$.

\begin{tabular}{ccccc}
\hline Compounds & $\begin{array}{c}\lambda_{\text {abs }}{ }^{\text {[a] }} \\
(\mathrm{nm})\end{array}$ & $\begin{array}{c}\boldsymbol{\varepsilon}^{\mathrm{a}]} \\
\left(\mathrm{M}^{-1} \cdot \mathrm{cm}^{-1}\right)\end{array}$ & $\begin{array}{c}\boldsymbol{\lambda}_{\mathrm{F}} \\
(\mathrm{nm})\end{array}$ & $\boldsymbol{\Phi}_{\text {solution }}{ }^{[\mathrm{b}]}$ \\
\hline 2a & 534 & 5500 & - & - \\
& 387 & 20800 & &
\end{tabular}




\begin{tabular}{|c|c|c|c|c|}
\hline \multirow[t]{4}{*}{$2 b$} & 567 & 10000 & - & - \\
\hline & 378 & 32000 & & \\
\hline & 330 & 18000 & & \\
\hline & 292 & 17000 & & \\
\hline \multirow[t]{3}{*}{ 3a } & 606 & 3500 & - & - \\
\hline & 420 & 11000 & & \\
\hline & 307 & 1800 & & \\
\hline \multirow[t]{3}{*}{$3 \mathbf{b}$} & 636 & 7500 & - & - \\
\hline & 410 & 16200 & & \\
\hline & 385 & 16900 & & \\
\hline $3 c$ & 395 & 39000 & - & - \\
\hline \multirow[t]{2}{*}{4} & 327 & 26000 & 360 & 0.745 \\
\hline & 258 & 6000 & & \\
\hline \multirow[t]{3}{*}{$5 a$} & 645 & 14500 & 358 & 0.007 \\
\hline & 419 & 57500 & & \\
\hline & 330 & 12500 & & \\
\hline \multirow[t]{3}{*}{$5 b$} & 799 & 78000 & - & \\
\hline & 432 & 26000 & & \\
\hline & 324 & 14000 & & \\
\hline \multirow[t]{2}{*}{$5 c$} & 406 & 40000 & 450 & 0.004 \\
\hline & 339 & 11500 & & \\
\hline \multirow[t]{2}{*}{$6 a$} & 550 & 7500 & & - \\
\hline & 365 & 32500 & & \\
\hline \multirow[t]{2}{*}{$6 b$} & 600 & 8200 & - & - \\
\hline & 368 & 32600 & & \\
\hline \multirow[t]{4}{*}{$8 a$} & 483 & 22000 & - & - \\
\hline & 376 & 122000 & & \\
\hline & 361 & 133000 & & \\
\hline & 248 & 86000 & & \\
\hline \multirow[t]{3}{*}{$8 b$} & 525 & 6600 & - & - \\
\hline & 383 & 36300 & & \\
\hline & 369 & 34400 & & \\
\hline \multirow[t]{2}{*}{ 8c } & 379 & 35000 & - & - \\
\hline & 365 & 39000 & & \\
\hline \multirow[t]{3}{*}{ 9a } & 500 & 19000 & - & - \\
\hline & 353 & 111000 & & \\
\hline & 289 & 45000 & & \\
\hline \multirow[t]{2}{*}{$9 b$} & 558 & 6700 & - & - \\
\hline & 369 & 34000 & & \\
\hline \multirow{4}{*}{$\begin{array}{c}9 \mathrm{c} \\
\mathrm{c}-\mathrm{CHO}\end{array}$} & 358 & 26500 & 440 & 0.002 \\
\hline & 460 & 6050 & - & - \\
\hline & 338 & 14000 & & \\
\hline & 268 & 69700 & & \\
\hline
\end{tabular}

The two absorption maxima of compound 5c are significantly red shifted compared to $\mathbf{4}$ and are observed at 406 and $339 \mathrm{~nm}$. This red shift is assigned to the extension of the $\pi$ conjugation induced by the presence of styryl fragment at the acetyl position of the DHA- 
difluoroboron complex. However, the introduction of a styryl arm appears to be detrimental for the luminescence properties of the DHA- $\mathrm{BF}_{2}$ core and only a weak emission centred at $450 \mathrm{~nm}$ is now observed upon excitation at $390 \mathrm{~nm}$ with a low quantum yield around $0.4 \%$. The replacement of the phenyl ring by a ferrocenyl donor group in 5a weakly affect the position of these two absorption bands but an additional intense and broad absorption band is observed at $645 \mathrm{~nm}$. This new band is attributed to a charge-transfer band (CT band) from the ferrocenyl donor to the DHA-BF 2 acceptor. It should be mentioned that Fc-CHO absorbs at much lower wavelengths. A weak emission at $358 \mathrm{~nm}$ was detected with compound 5a upon excitation at $300 \mathrm{~nm}$. The grafting of a ferrocenyl group does not really affect the luminescence properties the $\mathrm{DHA}-\mathrm{BF}_{2}$-styryl core. Electrochemical or chemical oxidation (with $\mathrm{NOBF}_{4}$ ) of compound $\mathbf{5 a}$ did not change the luminescence properties. An irreversible extinction of the luminescence was observed upon reduction at $-1 \mathrm{~V}$ vs ECS, likely attributed to the degradation of the compound. With a TTF fragment (5b), a CT band is also observed but at higher wavelength $(799 \mathrm{~nm})$ which is in line with a stronger donor character compare to a ferrocenyl fragment. Introduction of a styryl arm at the 6 position was also found to be detrimental for the luminescence properties of the $\mathrm{DHA}-\mathrm{BF}_{2}$ core since no emission could have been detected with 3a and $\mathbf{3 c}$ compounds. It can also be observed that the extension of the $\pi$-conjugation, i.e. bathochromic shift of the absorption bands, is much more effective at the acetyl position than in the 6 position. Removal of the $\mathrm{BF}_{2}$ fragment (compounds $\mathbf{2}$ and $\mathbf{6}$ ) leads to a blue shift of the absorption bands. This behaviour is likely attributed to a decrease of the rigidity and planarity between the DHA fragment and the carbonyl group. The same observation can also be made within the hydrazine series. The absorption spectra of $\mathbf{8 c}$, the DHA-hydrazone derivative carrying a phenyl ring, displays two strong absorption bands at 365 and $379 \mathrm{~nm}$. 8a carrying a ferrocene moiety shows the same main absorption peaks at 361 and $376 \mathrm{~nm}$ and the expected additional broad CT band due to the presence of the donor 
fragment on the hydrazone derivative is observed at $483 \mathrm{~nm}$. These two compounds were found to be non-luminescent in solution and in the solid state in contrary to the DHA-azino derivative 9c carrying a phenyl group and complexed by a $\mathrm{BF}_{2}$ fragment. The absorption spectra of 9c displays one main absorption band centred at $358 \mathrm{~nm}$. 9c is weakly luminescent in dichloromethane solution ( $\phi=0.2 \%$ ) but interestingly it was found that this compound is highly luminescent in the solid state. Upon excitation at $360 \mathrm{~nm}$, this compound shows a strong emission from 410 to $700 \mathrm{~nm}$ with a maximum centred at $469 \mathrm{~nm}$ (Figure 5). The solid state quantum yield measured with an integration sphere was found to be around $24 \%$ which is 120 times higher than in solution. The luminescence properties of 9c appear to be highly sensitive to the aggregation state and in the solid state a strong increase of the luminescence intensity is observed. This phenomenon can be described as an Aggregation Induced Enhancement Emission (AIEE) due to a restricted intramolecular motion ${ }^{17}$ or to J stacking. ${ }^{18}$ More interestingly, the colorimetric coordinate of the emitted light in the CIE diagram were found to be $\mathrm{x}=0.200$ and $\mathrm{y}=0.314$ which is close to white light $(\mathrm{x}=0.33$ and $\mathrm{y}=0.33)$.

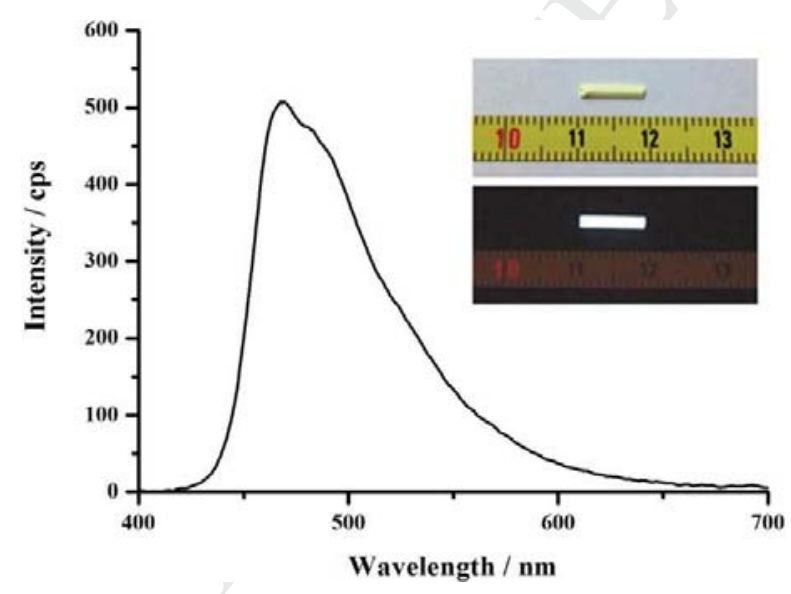

Figure 5. Solid state emission of compound 9c under excitation at $360 \mathrm{~nm}$ (inset: Photographs of a crystal of compound 9c under day light (top) and 254 nm UV light (bottom)). 


\section{Conclusion}

In conclusion, we prepared three types of $\mathrm{DHA}$ and $\mathrm{DHA}-\mathrm{BF}_{2}$ functionalized at different position by a benzene ring or an electroactive molecule (TTF or Fc). It is worth noting that the molecules where an azino linker is used to connect the DHA to the electrophore are more stable than those involving an ethylenic spacer group especially in the case of the boron difluoride complexes. Indeed, dioxaborine cycles can be easily hydrolyzed leading to the decomplexation while the enaminoketonato boron is more stable. The photophysical behavior of some of these difluoroboron complexes have been investigated. The DHA- $\mathrm{BF}_{2}$ was found highly luminescent in solution and we observed that substitution of this skeleton induces a significant decrease of the emission properties. Nevertheless, the most interesting derivative is the one where a phenyl ring is linked by an azino spacer group to the DHA- $\mathrm{BF}_{2}$ moiety. Indeed even if in solution this compound is weakly luminescent, in the solid state a strong increase of the luminescence is observed. Moreover, the colorimetric coordinate of the light emitted let us infer that a fine tuning of the substituent on this skeleton would allowed us to reach the white light.

\section{Experimental section}

\subsection{General}

${ }^{1} \mathrm{H}$ NMR, ${ }^{13} \mathrm{C}$ NMR, ${ }^{11} \mathrm{~B}$ NMR and ${ }^{19} \mathrm{~F}$ NMR spectra were recorded on a Bruker Avance 300 III spectrometer using $\mathrm{CDCl}_{3}$ as solvent unless otherwise stated. Chemical shifts are reported in parts per million. Mass spectra and elemental analysis results were performed by the Centre Régional de Mesures Physiques de l’Ouest (CRMPO), Rennes. Melting points were measured using a Kofler hot stage apparatus and are uncorrected. Cyclic voltammetry were carried out on a $10^{-3} \mathrm{M}$ solution of the compounds in dichloromethane, containing $0.1 \mathrm{M} \mathrm{n}-\mathrm{Bu}_{4} \mathrm{NPF}_{6}$ as 
supporting electrolyte. Voltammograms were recorded at $100 \mathrm{mV} \cdot \mathrm{s}^{-1}$ on a platinum disk electrode $\left(1 \mathrm{~mm}^{2}\right)$. The potentials were measured versus Saturated Calomel Electrode. Compounds $\mathbf{1}^{10}, \mathbf{2} \mathbf{c}^{10}, \mathbf{4}^{12}$ and $7^{13}$ were synthesized according to literature procedure. All the reagents were purchased and used without additional purification. UV-Vis spectra were recorded using a Cary $100 \mathrm{UV}$-Vis spectrophotometer (Varian) and $\mathrm{CH}_{2} \mathrm{Cl}_{2}$ as solvent. Photoluminescence spectra in solution were recorded with a Jobin-Yvon spectrofluorimeter. Quantum yields in solution ( $\phi$ sol) were calculated relative to $\left.\mathrm{Ru}(\mathrm{bipy})_{3}\right]_{\mathrm{Cl}} \mathrm{l}_{2}(\phi=0.059$ in $\mathrm{CH}_{3} \mathrm{CN}$ ). $\phi$ sol was determined according to the following equation,

$$
\phi \text { sol }=\phi r e f \times 100 \times\left[\left(T_{s} \times A_{r}\right) /\left(T_{r} \times A_{s}\right)\right] \times\left[\left(n_{s} / n_{r}\right)^{2}\right]
$$

where, subscripts s and $r$ refer respectively to the sample and reference. The integrated area of the emission peak in arbitrary units is given as $\mathrm{T}, \mathrm{n}$ is the refracting index of the solvent $(\mathrm{n}=$ 1.3404 for acetonitrile, $\mathrm{n}=1.4242$ for dichloromethane and $\mathrm{n}=1.4305$ for DMF) and $\mathrm{A}$ is the absorbance. Absolute quantum yield and CIE coordinates were measured with a Hamamatsu C9920-03G system.

\subsection{Synthesis and characterization}

General procedure for the synthesis of $\mathbf{2 a}, \boldsymbol{b}$. To a solution of phosphonium salt $\mathbf{1}$ (0.75 mmol, $382 \mathrm{mg})$ in $10 \mathrm{~mL}$ of dry DMF at $0^{\circ} \mathrm{C}$ was slowly added $1.5 \mathrm{~mL}(1.5 \mathrm{mmol})$ of freshly prepared $1 \mathrm{M}$ sodium methanolate solution under inert atmosphere. The reaction was kept at room temperature for $1 / 2 \mathrm{~h}$ and ferrocenecarboxaldehyde $(0.7 \mathrm{mmol}, 150 \mathrm{mg})$ or $\mathrm{Me}_{3}$ TTFcarboxaldehyde $(0.7 \mathrm{mmol}, 192 \mathrm{mg})$ in dry DMF $(10 \mathrm{~mL})$ was slowly added. The solution was left overnight under stirring. The medium was acidified with $1 \mathrm{M} \mathrm{HCl}$ solution (0.8 mL, $0.8 \mathrm{mmol}$ ) and DMF was evaporated. The resulting solid was extracted with $\mathrm{CH}_{2} \mathrm{Cl}_{2}$ and washed with water and subjected to column chromatography on silica gel with $\mathrm{CH}_{2} \mathrm{Cl}_{2} / \mathrm{PE}$ (3/1) as eluent. 
2a (56 mg) was obtained as a deep purple solid in $22 \%$ yield; mp $172-174{ }^{\circ} \mathrm{C}$; ${ }^{1} \mathrm{H}$ NMR (CDCl, $300 \mathrm{MHz}) \delta(\mathrm{ppm}) 2.70$ (s, 3H, $\mathrm{CH}_{3}$ ), 4.20 (s, 5H, Cp), 4.52 (m, 2H, Cp), 4.62 (m, 2H, Cp), 5.93 (s, 1H, =CH), $6.21(\mathrm{~d}, 1 \mathrm{H}, J=15 \mathrm{~Hz},=\mathrm{CH}), 7.59$ (d, $1 \mathrm{H}, J=15 \mathrm{~Hz},=\mathrm{CH}$ ), 16.63 (s, 1H, OH); ${ }^{13} \mathrm{C}$ NMR $\left(\mathrm{CDCl}_{3}, 75 \mathrm{MHz}\right) \delta(\mathrm{ppm})$ 30.3, 68.7, 70.0, 71.7, 79.3, 99.2, 100.1, 114.8, 142.32, 161.1, 164.1, 180.8, 204.7; UV-Vis $\lambda(\varepsilon)=387$ nm (20 800), 534 nm (5 500); IR $\left(\mathrm{cm}^{-1}\right) v=1712,1610,1545$; HRMS calc. for $\mathrm{M}^{+} \cdot\left(\mathrm{C}_{19} \mathrm{H}_{16}{ }^{56} \mathrm{FeO}_{4}\right): 364.0398$, found : 364.0399.

2b (169 mg) was obtained as a deep purple solid in $57 \%$ yield; mp $>250^{\circ} \mathrm{C}$ (decomp.); ${ }^{1} \mathrm{H} \mathrm{NMR}\left(\mathrm{CDCl}_{3}, 300 \mathrm{MHz}\right) \delta$ (ppm) 1.96 (s, 6H, $\left.\mathrm{CH}_{3}\right), 2.26$ (s, 3H, $\left.\mathrm{CH}_{3}\right), 2.68$ (s, 3H, $\left.\mathrm{CH}_{3}\right), 5.80(\mathrm{~d}, 1 \mathrm{H}, J=15 \mathrm{~Hz},=\mathrm{CH}) ; 5.98(\mathrm{~s}, 1 \mathrm{H},=\mathrm{CH}), 7.36(\mathrm{~d}, 1 \mathrm{H}, J=15 \mathrm{~Hz},=\mathrm{CH}), 16.61$ (s, 1H, OH); UV-Vis $\lambda(\varepsilon)=292 \mathrm{~nm}(17000), 330 \mathrm{~nm}(18000), 378 \mathrm{~nm}(32000), 567 \mathrm{~nm}$ (10 000); IR $\left(\mathrm{cm}^{-1}\right) v=1703,1593,1542,1519$; HRMS calc. for $\mathrm{M}^{+} \cdot\left(\mathrm{C}_{18} \mathrm{H}_{16} \mathrm{O}_{4} \mathrm{~S}_{4}\right)$ : 423.9931, found : 423.9926.

General procedure for the synthesis of $3 \mathbf{a}-\mathbf{c}$. To a solution of $2(0.25 \mathrm{mmol}, 91 \mathrm{mg}$ of $\mathbf{2 a}, 106$ $\mathrm{mg}$ of $\mathbf{2} \mathbf{b}, 64 \mathrm{mg}$ of $\mathbf{2 c}$ ) in toluene ( $5 \mathrm{~mL}$ ) was added dropwise at room temperature and under inert atmosphere $63 \mu \mathrm{L}$ of boron trifluoride etherate $(0.5 \mathrm{mmol})$. A black solid precipitated immediately which was filtered under vacuum, washed with toluene and dried. For 3c, the reaction was refluxed $1 \mathrm{~h}$ and the yellow precipitate was filtrated under vacuum, washed with toluene and dried.

3a (98 mg) was obtained as a deep green solid in $95 \%$ yield; mp $>250^{\circ} \mathrm{C}$ (decomp.); ${ }^{1} \mathrm{H}$ $\operatorname{NMR}\left(\mathrm{CDCl}_{3}, 300 \mathrm{MHz}\right) \delta$ (ppm) 2.84 (s, 3H, $\mathrm{CH}_{3}$ ), 4.23 (s, 5H, Cp), 4.64 (m, 2H, Cp), 4.69 (m, 2H, Cp), 6.04 (s, 1H, =CH), 6.27 (d, 1H, J=15Hz, =CH), 7.84 (d, $1 \mathrm{H}, J=15 \mathrm{~Hz},=\mathrm{CH}) ;{ }^{13} \mathrm{C}$ $\operatorname{NMR}\left(\mathrm{CDCl}_{3}, 75 \mathrm{MHz}\right) \delta(\mathrm{ppm})$ 26.5, 69.9, 70.8, 73.6, 77.3, 99.2, 107.5, 113.9, 148.4, 158.7, 168.6, 178.0, 197.7; ${ }^{11} \mathrm{~B}$ NMR $\left(\mathrm{CDCl}_{3}, 96 \mathrm{MHz}\right) \delta(\mathrm{ppm})-0.03 ;{ }^{19} \mathrm{~F} \mathrm{NMR}\left(\mathrm{CDCl}_{3}, 282 \mathrm{MHz}\right)$ 
$\delta(\mathrm{ppm})$-141.3; UV-Vis $\lambda(\varepsilon)=307 \mathrm{~nm}$ (1800), $420 \mathrm{~nm}$ (11 000), $606 \mathrm{~nm}$ (3 500); IR $\left(\mathrm{cm}^{-1}\right) v$ = 1749, 1580, 1496; HRMS calc. for $\mathrm{M}^{+} \cdot\left(\mathrm{C}_{19} \mathrm{H}_{15} \mathrm{O}_{4} \mathrm{~F}_{2}{ }^{11} \mathrm{~B}^{56} \mathrm{Fe}\right): 412.0381$, found : 412.0380 .

3b (111 mg) was obtained as a deep purple solid in 94\% yield; $\mathrm{mp}=220{ }^{\circ} \mathrm{C}$ (decomp.); ${ }^{1} \mathrm{H}$ NMR $\left(\mathrm{CD}_{3} \mathrm{CN}, 300 \mathrm{MHz}\right) \delta$ (ppm) 2.31 (s, 3H, $\mathrm{CH}_{3}$ ), 2.65 (s, 6H, $\mathrm{CH}_{3}$ ), 2.79 (s, 3H, $\left.\mathrm{CH}_{3}\right), 6.22$ (d, $\left.1 \mathrm{H}, \mathrm{J}=15 \mathrm{~Hz},=\mathrm{CH}\right), 6.49$ (s, $\left.1 \mathrm{H},=\mathrm{CH}\right), 7.60$ (d, $\left.1 \mathrm{H}, \mathrm{J}=15 \mathrm{~Hz},=\mathrm{CH}\right) .{ }^{11} \mathrm{~B}$ NMR (CDCl 3 , $96 \mathrm{MHz}) \delta(\mathrm{ppm})-0.99 ;{ }^{19} \mathrm{~F} \mathrm{NMR}\left(\mathrm{CDCl}_{3}, 282 \mathrm{MHz}\right) \delta$ (ppm) -150.6; UV-Vis $\lambda(\varepsilon)=385 \mathrm{~nm}$ (16 900), $410 \mathrm{~nm}$ (16 200), $636 \mathrm{~nm}$ (7 500); IR $\left(\mathrm{cm}^{-1}\right) v=1740,1620,1458$; HRMS calc. for $\mathrm{M}^{+} \cdot\left(\mathrm{C}_{18} \mathrm{H}_{15} \mathrm{O}_{4} \mathrm{~F}_{2}{ }^{11} \mathrm{BS}_{4}\right)$ : 471.9914, found : 471.9924.

3c (70 mg) was obtained after precipitation in $\mathrm{CH}_{2} \mathrm{Cl}_{2}$ as yellow crystals in $92 \%$ yield; mp $240^{\circ} \mathrm{C}$ (decomp.); ${ }^{1} \mathrm{H}$ NMR $\left(\mathrm{CDCl}_{3}, 300 \mathrm{MHz}\right) \delta(\mathrm{ppm}) 2.89$ (s, 3H, $\left.\mathrm{CH}_{3}\right), 6.22(\mathrm{~s}, 1 \mathrm{H}$, $=\mathrm{CH}), 6.73(\mathrm{~d}, 1 \mathrm{H}, J=17 \mathrm{~Hz},=\mathrm{CH}) ; 7.42-7.48(\mathrm{~m}, 3 \mathrm{H}, \mathrm{Ar}), 7.61(\mathrm{~m}, 2 \mathrm{H}, \mathrm{Ar}) ; 8.83(\mathrm{~d}, 1 \mathrm{H}$, $J=17 \mathrm{~Hz},=\mathrm{CH}) ;{ }^{11} \mathrm{~B}$ NMR $\left(\mathrm{CDCl}_{3}, 96 \mathrm{MHz}\right) \delta(\mathrm{ppm})-0.02 ;{ }^{19} \mathrm{~F} \mathrm{NMR}\left(\mathrm{CDCl}_{3}, 282 \mathrm{MHz}\right) \delta$ (ppm) -140.4; UV-Vis $\lambda(\varepsilon)=395 \mathrm{~nm}(39000)$; IR $\left(\mathrm{cm}^{-1}\right) v=1756,1629,1600,1509$; HRMS calc. for $[\mathrm{M}+\mathrm{H}]^{+}\left(\mathrm{C}_{15} \mathrm{H}_{12} \mathrm{O}_{4} \mathrm{~F}_{2}{ }^{11} \mathrm{~B}\right)$ : 305.0791, found : 305.0795

General procedure for the synthesis of 5a-c. To a hot solution of DHA-BF 4 (216 mg, 1 mmol) in $3 \mathrm{~mL}$ of acetic anhydride $\left(60^{\circ} \mathrm{C}\right)$ was added a solution of ferrocenecarboxaldehyde (214 mg, $1 \mathrm{mmol}$ ) or a suspension of trimethylTTF-aldehyde (274 mg, $1 \mathrm{mmol}$ ) or a solution of benzaldehyde ( $153 \mu \mathrm{L}, 1.5 \mathrm{mmol}$ ) in $2 \mathrm{~mL}$ of acetic anhydride. The reaction was heated to $90^{\circ} \mathrm{C}$ for $45 \mathrm{~min}$. After cooling, the precipitate was filtered and washed with acetic acid and water.

5a (247 mg) was obtained in $60 \%$ yield as a deep green powder; $\mathrm{mp} 250^{\circ} \mathrm{C}$ (decomp.); ${ }^{1} \mathrm{H}$ NMR (CDCl $\left.3,300 \mathrm{MHz}\right) \delta(\mathrm{ppm}) 2.33$ (s, 3H, $\mathrm{CH}_{3}$ ), 4.30 (s, 5H, Cp), 4.83 (s, 2H, Cp), 4.93 (s, 2H, Cp), 6.09 (s, 1H, =CH), 7.84 (d, 1H, =CH, $J=16$ Hz), 8.59 (d, 1H, =CH, J=16 $\mathrm{Hz}) ;{ }^{13} \mathrm{C} \mathrm{NMR}\left(\mathrm{CDCl}_{3}, 75 \mathrm{MHz}\right) \delta(\mathrm{ppm})$ 21.1, 71.5, 71.7, 76.1, 79.1, 98.36, 130.1, 114.6, 
159.3, 160.6, 171.8, 178.4, 179.8; ${ }^{11} \mathrm{~B}$ NMR $\left(\mathrm{CDCl}_{3}, 96 \mathrm{MHz}\right) \delta(\mathrm{ppm})-0.05 ;{ }^{19} \mathrm{~F}$ NMR $\left(\mathrm{CDCl}_{3}, 282 \mathrm{MHz}\right) \delta(\mathrm{ppm})$-143.3; UV-Vis $\lambda(\varepsilon)=330 \mathrm{~nm}$ (12 500), 419 nm (57 500), 645 nm (14 500); IR ( $\left.\mathrm{cm}^{-1}\right) v=1739,1632,1591,1475$; HRMS calc. for $\mathrm{M}^{+} \cdot\left(\mathrm{C}_{19} \mathrm{H}_{15} \mathrm{BF}_{2}{ }^{56} \mathrm{FeO}_{4}\right)$; 412.0381, found: 412.0387; Anal. Calcd for $\mathrm{C}_{19} \mathrm{H}_{15} \mathrm{BF}_{2} \mathrm{FeO}_{4}$ : C, 55.39, H, 3.67, found C, 55.65, H, $3.63 \%$.

5b was extracted with $\mathrm{CH}_{2} \mathrm{Cl}_{2}$ and subjected to column chromatography using first $\mathrm{CH}_{2} \mathrm{Cl}_{2} / \mathrm{PE}(1 / 2)$ and then $\mathrm{CH}_{2} \mathrm{Cl}_{2}$ as eluent. $5 \mathbf{b}$ (33 mg) was obtained in $7 \%$ yield as a green powder; mp $>260^{\circ} \mathrm{C}$; ${ }^{1} \mathrm{H}$ NMR $\left(\mathrm{CDCl}_{3}, 300 \mathrm{MHz}\right) \delta(\mathrm{ppm}) 1.97$ (s, 3H, $\left.\mathrm{CH}_{3}\right), 1.98(\mathrm{~s}, 3 \mathrm{H}$, $\mathrm{CH}_{3}$ ), 2.37 (s, 3H, $\mathrm{CH}_{3}$ ), 2.41 (s, 3H, $\mathrm{CH}_{3}$ ), 6.09 (s, 1H, =CH), 7.42 (d, 1H, =CH, J=15 Hz), $8.08(\mathrm{~d}, 1 \mathrm{H},=\mathrm{CH}, J=15 \mathrm{~Hz}) ;{ }^{11} \mathrm{~B} \mathrm{NMR}\left(\mathrm{CDCl}_{3}, 96 \mathrm{MHz}\right) \delta(\mathrm{ppm}) 0.08 ;{ }^{19} \mathrm{~F}$ NMR $\left(\mathrm{CDCl}_{3}\right.$, $282 \mathrm{MHz}) \delta(\mathrm{ppm})$-142.6; UV-Vis $\lambda(\varepsilon)=324 \mathrm{~nm}$ (14 000), $432 \mathrm{~nm}$ (26 000), 799 nm (78 000); IR $\left(\mathrm{cm}^{-1}\right) \quad v=2920,1729,1641,1583,1466,1402$; HRMS calc. for $\mathrm{M}^{+}$. $\left(\mathrm{C}_{18} \mathrm{H}_{15} \mathrm{BF}_{2} \mathrm{O}_{4} \mathrm{~S}_{4}\right): 471.9909$, found: 471.9910.

5c was purified by column chromatography using $\mathrm{CH}_{2} \mathrm{Cl}_{2} / \mathrm{PE}(4 / 1)$ as eluent. 5c (36 mg) was obtained in $12 \%$ yield as a pale yellow powder; mp $254^{\circ} \mathrm{C}$ (decomp.) ; ${ }^{1} \mathrm{H}$ NMR $\left(\mathrm{CDCl}_{3}, 300 \mathrm{MHz}\right) \delta(\mathrm{ppm}) 2.40\left(\mathrm{~s}, 3 \mathrm{H}, \mathrm{CH}_{3}\right), 6.16(\mathrm{~s}, 1 \mathrm{H},=\mathrm{CH}), 7.46-7.59$ (m, 3H, Ar), $7.78(\mathrm{~m}, 2 \mathrm{H}, \mathrm{Ar}), 8.40$ (d, $1 \mathrm{H},=\mathrm{CH}, \mathrm{J}=15 \mathrm{~Hz}), 8.46(\mathrm{~d}, 1 \mathrm{H},=\mathrm{CH}, \mathrm{J}=15 \mathrm{~Hz}) ;{ }^{13} \mathrm{C}$ NMR $\left(\mathrm{CDCl}_{3}, 75 \mathrm{MHz}\right) \delta(\mathrm{ppm}) 21.4,103.0,118.9,129.2,129.6,130.8,133.7,134.0,155.1,159.0$, 174.3, 180.0, 184.8; ${ }^{11} \mathrm{~B}$ NMR $\left(\mathrm{CDCl}_{3}, 96 \mathrm{MHz}\right) \delta$ (ppm) 0.14; ${ }^{19} \mathrm{~F} \mathrm{NMR}\left(\mathrm{CDCl}_{3}, 282 \mathrm{MHz}\right)$ $\delta$ (ppm) -141.9; UV-Vis $\lambda(\varepsilon)=339 \mathrm{~nm}(11500), 406 \mathrm{~nm}\left(40\right.$ 000); IR $\left(\mathrm{cm}^{-1}\right) v=2925,1732$, 1631, 1618, 1539, 1501; HRMS calc. for $[\mathrm{M}+\mathrm{H}]^{+}\left(\mathrm{C}_{15} \mathrm{H}_{12} \mathrm{~F}_{2} \mathrm{O}_{4}{ }^{11} \mathrm{~B}\right):$ 305.0791, found : 305.0796 .

General procedure for the synthesis of $\mathbf{6 a}, \boldsymbol{b}$. To difluoroborane complex $\mathbf{5 a}(100 \mathrm{mg}, 0.24$ mmol) or $5 \mathbf{b}$ (20 mg, $0.042 \mathrm{mmol})$ was added sodium carbonate (1.0 g, $0.94 \mathrm{mmol})$ dissolved 
in a mixture of water $(5 \mathrm{~mL})$ and EtOH $(5 \mathrm{~mL})$. The medium was refluxed for $2 \mathrm{~h}$. The reaction mixture was cooled and treated with a solution of hydrochloric acid till $\mathrm{pH}$ reached 6.5-7. The precipitate that formed was filtered, extracted with $\mathrm{CH}_{2} \mathrm{Cl}_{2}$, washed with water and dried over magnesium sulfate. The product was purified by column chromatography using $\mathrm{CH}_{2} \mathrm{Cl}_{2} / \mathrm{PE}(4 / 1)$ as eluent.

6a (65 mg) was obtained as a deep purple powder in $75 \%$ yield ; mp $159-160{ }^{\circ} \mathrm{C}$; ${ }^{1} \mathrm{H}$ NMR (CDCl $3,300 \mathrm{MHz}) \delta$ (ppm) 2.25 (s, 3H, CH ) $_{3} 4.20$ (s, 5H, Cp), 4.57 (s, 2H, Cp), 4.68 (s, 2H, Cp), 5.92 (s, 1H, =CH), 7.86 (d, 1H, =CH, $J=16 \mathrm{~Hz}$ ), 7.99 (d, 1H, =CH, $J=16 \mathrm{~Hz}$ ); ${ }^{13} \mathrm{C}$ $\operatorname{NMR}\left(\mathrm{CDCl}_{3}, 75 \mathrm{MHz}\right) \delta(\mathrm{ppm})$ 20.6, 69.9, 70.1, 72.4, 79.0, 98.9, 102.9, 119.3, 150.0, 161.4, 167.8, 183.7, 190.9; UV-Vis $\lambda(\varepsilon)=365$ nm (32 500), $550 \mathrm{~nm}$ (7 500); IR $\left(\mathrm{cm}^{-1}\right) v=1716$, 1652, 1609, 1504; HRMS calc. for $\mathrm{M}^{+} .\left(\mathrm{C}_{19} \mathrm{H}_{16}{ }^{56} \mathrm{FeO}_{4}\right)$ : 364.0398, found: 364.0410 .

6b (11 mg) was obtained as a deep blue powder in $64 \%$ yield ; mp $>250{ }^{\circ} \mathrm{C} ;{ }^{1} \mathrm{H}$ NMR $\left(\mathrm{CDCl}_{3}, 300 \mathrm{MHz}\right) \delta(\mathrm{ppm}) 1.95$ (s, 3H, $\left.\mathrm{CH}_{3}\right), 1.96$ (s, 3H, $\left.\mathrm{CH}_{3}\right), 2.27$ (s, 6H, $\left.\mathrm{CH}_{3}\right), 5.93$ (s, $1 \mathrm{H},=\mathrm{CH}), 7.46$ (d, 1H, =CH, $J=15 \mathrm{~Hz}), 7.73(\mathrm{~d}, 1 \mathrm{H},=\mathrm{CH}, J=15 \mathrm{~Hz}), 17.89$ (s, $1 \mathrm{H}, \mathrm{OH}) ;{ }^{13} \mathrm{C}$ NMR $\left(\mathrm{CDCl}_{3}, 75 \mathrm{MHz}\right) \delta(\mathrm{ppm})$ 13.8, 14.8, 20.8, 99.6, 102.5, 113.1, 122.7, 123.4, 124.0, 128.9, 129.6, 133.1, 144.8, 161.1, 168.7, 183.1, 192.0; UV-Vis $\lambda(\varepsilon)=368 \mathrm{~nm}(32$ 600), 600 nm (8 200); IR $\left(\mathrm{KBr}, \mathrm{cm}^{-1}\right) v=2921,1716,1638,1618,1509$; HRMS calc. for $\mathrm{M}^{+}$. $\left(\mathrm{C}_{18} \mathrm{H}_{16} \mathrm{O}_{4} \mathrm{~S}_{4}\right): 423.9926$, found: 423.9930

General procedure for the synthesis of $\mathbf{8 a}, \boldsymbol{b}$. To a solution of DHA-hydrazone 7 (182 mg, 1 mmol) in THF (15 mL) was added ferrocenecarboxaldehyde (214 $\mathrm{mg}, 1 \mathrm{mmol}$ ) or $\mathrm{Me}_{3}$ TTFcarboxaldehyde (274 mg, $1 \mathrm{mmol}$ ) and $2 \mathrm{~mL}$ of $\mathrm{HCl} 2 \mathrm{M}$. The reaction mixture was refluxed $2 \mathrm{~h}$. The solvent was removed under vacuum, the solid was extracted with $\mathrm{CH}_{2} \mathrm{Cl}_{2}$, washed with water and dried over $\mathrm{MgSO}_{4}$. 
8a was purified by column chromatography using $\mathrm{CH}_{2} \mathrm{Cl}_{2}$ as eluent to afford a red solid in $74 \%$ yield $(280 \mathrm{mg})$; mp $154{ }^{\circ} \mathrm{C} ;{ }^{1} \mathrm{H}$ NMR $\left(\mathrm{CDCl}_{3}, 300 \mathrm{MHz}\right) \delta(\mathrm{ppm}) 2.16(\mathrm{~s}, 3 \mathrm{H}$, $\mathrm{CH}_{3}$ ), 2.89 (s, 3H, $\mathrm{CH}_{3}$ ), 4.23 (s, 5H, Cp), 4.53 (s, 2H, Cp), 4.69 (s, 2H, Cp), 5.75 (s, 1H, $=\mathrm{CH}), 8.20(\mathrm{~s}, 1 \mathrm{H},=\mathrm{CH}), 16.71(\mathrm{~s}, 1 \mathrm{H}, \mathrm{OH}) ;{ }^{13} \mathrm{C} \mathrm{NMR}\left(\mathrm{CDCl}_{3}, 75 \mathrm{MHz}\right) \delta(\mathrm{ppm}) 17.2,20.0$, 68.8, 69.6, 71.8, 76.5, 95.6, 107.2, 156.4, 163.2, 163.5, 170.9, 184.5; UV-Vis $\lambda(\varepsilon)=248 \mathrm{~nm}$ (86 000), $361 \mathrm{~nm}$ (133 000), $376 \mathrm{~nm}$ (122 000), $483 \mathrm{~nm}$ (22 000); IR $\left(\mathrm{cm}^{-1}\right) v=1707,1659$, 1600, 1562; HRMS calc. for $\mathrm{M}^{+} \cdot\left(\mathrm{C}_{19} \mathrm{H}_{18} \mathrm{~N}_{2} \mathrm{O}_{3}{ }^{56} \mathrm{Fe}\right)$ : 378.0667, found: 378.0672 . Anal. Calcd for $\mathrm{C}_{19} \mathrm{H}_{18} \mathrm{FeN}_{2} \mathrm{O}_{3}$ : C, 60.34, H, 4.80, N, 7.41, found C, 60.04, H, 4.73, N, $7.10 \%$.

8b was purified by column chromatography using $\mathrm{CH}_{2} \mathrm{Cl}_{2} / \mathrm{MeOH}(9.8 / 0.2)$ as eluent to afford a deep purple powder in 53\% yield (232 mg); mp $274{ }^{\circ} \mathrm{C} ;{ }^{1} \mathrm{H}$ NMR $\left(\mathrm{CDCl}_{3}, 300\right.$ MHz) $\delta(\mathrm{ppm}) 1.96\left(\mathrm{~s}, 6 \mathrm{H}, \mathrm{CH}_{3}\right), 2.17$ (s, 3H, $\left.\mathrm{CH}_{3}\right), 2.26\left(\mathrm{~s}, 3 \mathrm{H}, \mathrm{CH}_{3}\right), 2.88\left(\mathrm{~s}, 3 \mathrm{H}, \mathrm{CH}_{3}\right)$, 5.74 (s, 1H, CH), 8.09 (s, 1H, CH=N); ${ }^{13} \mathrm{C} \mathrm{NMR}\left(\mathrm{CDCl}_{3}, 75 \mathrm{MHz}\right) \delta(\mathrm{ppm})$ 12.7, 12.7, 13.4, 16.0, 18.9, 95.1, 105.8, 112.1, 121.7, 122.1, 142.6, 142.8, 142.9, 162.0, 162.7, 171.6, 183.6; UV-vis $\lambda$ (ع) 369 nm (34 400), 383 nm (36 300), 525 nm (6 600); IR $\left(\mathrm{cm}^{-1}\right) v=1616,1590$; HRMS calc. for $\mathrm{M}^{+} \cdot\left(\mathrm{C}_{18} \mathrm{H}_{18} \mathrm{~N}_{2} \mathrm{O}_{3} \mathrm{~S}_{4}\right) 438.0200$, found 438.0194 .

Synthesis of $\mathbf{8 c}$. To a solution of DHA-hydrazone 7 (546 mg, $3 \mathrm{mmol}$ ) in absolute EtOH (15 $\mathrm{mL}$ ) was added benzaldehyde $(0.3 \mathrm{~mL}, 3 \mathrm{mmol})$. The reaction mixture was refluxed for $3 \mathrm{~h}$. The solvent was removed under vacuum and the solid was subjected to column chromatography using $\mathrm{CH}_{2} \mathrm{Cl}_{2} / \mathrm{PE}$ (4/1) as eluent to afford $\mathbf{8 c}$ (608 $\mathrm{mg}$ ) in $75 \%$ yield as a pale yellow powder; mp $199^{\circ} \mathrm{C} ;{ }^{1} \mathrm{H}$ NMR $\left(\mathrm{CDCl}_{3}, 300 \mathrm{MHz}\right) \delta(\mathrm{ppm}) 2.17$ (s, 3H, $\left.\mathrm{CH}_{3}\right), 3.00(\mathrm{~s}$, 3H, $\mathrm{CH}_{3}$ ), 5.76 (s, $\left.1 \mathrm{H},=\mathrm{CH}\right), 7.43-7.52$ (m, 3H, Ar), 7.66 (d, 2H, J=8 Hz, Ar); 8.29 (s, $1 \mathrm{H}$, $\mathrm{N}=\mathrm{CH}) ;{ }^{13} \mathrm{C} \mathrm{NMR}\left(\mathrm{CDCl}_{3}, 75 \mathrm{MHz}\right) \delta(\mathrm{ppm}) 17.1,19.9,96.0,107.0,128.3,129.0,131.8$, 132.7, 154.3, 163.1, 163.5, 172.9, 184.6; UV-Vis $\lambda(\varepsilon)=365 \mathrm{~nm}$ (39 000), $379 \mathrm{~nm}$ (35 000); IR $\left(\mathrm{cm}^{-1}\right) v=2958,2923,1702,1656,1608,1574,1553$; HRMS calc. for $[\mathrm{M}+\mathrm{Na}]^{+}$ 
$\mathrm{C}_{15} \mathrm{H}_{14} \mathrm{~N}_{2} \mathrm{O}_{3} \mathrm{Na}$ : 293.0902, found : 293.0904; Anal. Calcd for $\mathrm{C}_{15} \mathrm{H}_{14} \mathrm{~N}_{2} \mathrm{O}_{3}$ : C, 66.66, H, 5.22, N, 10.36; found C, 66.59, H, 5.10, N, $10.31 \%$.

General procedure for the synthesis of $\mathbf{9 a}$-c. An excess of Et2O.BF3 (0.63 mL, $5 \mathrm{mmol})$ was added to a solution of $\mathbf{8 a}(189 \mathrm{mg}, 0.5 \mathrm{mmol})$ or $\mathbf{8 b}$ (220 mg, $0.5 \mathrm{mmol}) \mathbf{8 c}(135 \mathrm{mg}, 0.5$ mmol) containing dry $\mathrm{NEt}_{3}(0.21 \mathrm{~mL}, 1.5 \mathrm{mmol})$ in $15 \mathrm{~mL}$ of dry and degassed $\mathrm{CH}_{2} \mathrm{Cl}_{2}$ under inert atmosphere. The reaction mixture was stirred at room temperature for $12 \mathrm{~h}$. The organic phase was washed with water and dried over $\mathrm{MgSO}_{4}$ and subjected to column chromatography using $\mathrm{CH}_{2} \mathrm{Cl}_{2}$ as eluent.

9a (164 mg) was obtained as a red solid in $77 \%$ yield; mp $206^{\circ} \mathrm{C} ;{ }^{1} \mathrm{H}$ NMR $\left(\mathrm{CDCl}_{3}\right.$, $300 \mathrm{MHz}) \delta(\mathrm{ppm}) 2.31$ (s, 3H, $\mathrm{CH}_{3}$ ), 2.81 (s, 3H, $\mathrm{CH}_{3}$ ), 4.32 (s, 5H, Cp), 4.58 (t, 2H, J = 2Hz, Cp), 4.76 (s, 2H, J = 2Hz, Cp), 6.07 (s, 1H, =CH), 8.63 (s, 1H, =CH); ${ }^{13} \mathrm{C} \mathrm{NMR}\left(\mathrm{CDCl}_{3}\right.$, $75 \mathrm{MHz}) \delta$ (ppm) 17.9, 20.6, 69.4, 70.0, 72.5, 77.2, 96.7, 102.4, 160.5, 164.8, 167.6, 168.8, 172.3; ${ }^{11} \mathrm{~B}$ NMR $\left(\mathrm{CDCl}_{3}, 96 \mathrm{MHz}\right) \delta(\mathrm{ppm})-19.39 ;{ }^{19} \mathrm{~F} \mathrm{NMR}\left(\mathrm{CDCl}_{3}, 282 \mathrm{MHz}\right) \delta(\mathrm{ppm})-$ 136.6; UV-Vis $\lambda(\varepsilon)=289 \mathrm{~nm}$ (45 000), $353 \mathrm{~nm}$ (111 000), $500 \mathrm{~nm}$ (19 000); IR ( $\left.\mathrm{cm}^{-1}\right) v=$ 1712, 1650, 1609, 1562, 1506; HRMS calc. for $\mathrm{M}^{+} \cdot\left(\mathrm{C}_{19} \mathrm{H}_{17} \mathrm{~N}_{2} \mathrm{O}_{3} \mathrm{~F}_{2}{ }^{11} \mathrm{~B}^{56} \mathrm{Fe}\right)$ : 426.0650, found: 426.0660 .

9b (56 mg) was obtained as a red solid in $23 \%$ yield; mp $>260{ }^{\circ} \mathrm{C} ;{ }^{1} \mathrm{H}$ NMR $\left(\mathrm{CDCl}_{3}\right.$, $300 \mathrm{MHz}) \delta(\mathrm{ppm}) 1.96\left(\mathrm{~s}, 6 \mathrm{H}, \mathrm{CH}_{3}\right), 2.33\left(\mathrm{~s}, 3 \mathrm{H}, \mathrm{CH}_{3}\right), 2.92$ (s, 3H, $\left.\mathrm{CH}_{3}\right), 6.06(\mathrm{~s}, 1 \mathrm{H}$, $=\mathrm{CH}), 8.65(\mathrm{~s}, 1 \mathrm{H},=\mathrm{CH}) ;{ }^{11} \mathrm{~B} \mathrm{NMR}\left(\mathrm{CDCl}_{3}, 96 \mathrm{MHz}\right) \delta(\mathrm{ppm})-0.14 ;{ }^{19} \mathrm{~F} \mathrm{NMR}\left(\mathrm{CDCl}_{3}, 282\right.$ MHz) $\delta(\mathrm{ppm})$-136.4; UV-Vis $\lambda(\varepsilon)=369$ nm (34 000), 558 nm (6 700); HRMS calc. for $\mathrm{M}^{+}$. $\left(\mathrm{C}_{18} \mathrm{H}_{17} \mathrm{~N}_{2} \mathrm{O}_{3} \mathrm{~F}_{2}{ }^{11} \mathrm{~B}\right): 486.01832$, found: 486.0184 .

9c (95 mg) was obtained as a yellow solid in $60 \%$ yield; mp $202{ }^{\circ} \mathrm{C} ;{ }^{1} \mathrm{H} \mathrm{NMR}\left(\mathrm{CDCl}_{3}\right.$, $300 \mathrm{MHz}) \delta(\mathrm{ppm}) 2.34$ (s, 3H, $\left.\mathrm{CH}_{3}\right), 2.96\left(\mathrm{~s}, 3 \mathrm{H}, \mathrm{CH}_{3}\right), 6.08(\mathrm{~s}, 1 \mathrm{H},=\mathrm{CH}), 7.45-7.57(\mathrm{~m}, 3 \mathrm{H}$, Ar), 7.86 (d, 2H, J=6 Hz, Ar); 8.78 (s, $1 \mathrm{H},=\mathrm{CH}) ;{ }^{13} \mathrm{C} \mathrm{NMR}\left(\mathrm{CDCl}_{3}, 75 \mathrm{MHz}\right) \delta$ (ppm) 18.2, 
20.7, 96.9, 102.4, 129.1, 129.2, 132.8, 132.9, 160.4, 162.4, 169.7, 170.4, 173.0; ${ }^{11} \mathrm{~B}$ NMR $\left(\mathrm{CDCl}_{3}, 96 \mathrm{MHz}\right) \delta(\mathrm{ppm})-0.07 ;{ }^{19} \mathrm{~F} \mathrm{NMR}\left(\mathrm{CDCl}_{3}, 282 \mathrm{MHz}\right) \delta-136.6$; UV-Vis $\lambda(\varepsilon)=358$ nm (26 500); IR $\left(\mathrm{cm}^{-1}\right) \quad v=1731,1637,1510,1449$; HRMS calc. for $[\mathrm{M}+\mathrm{Na}]^{+}$ $\mathrm{C}_{15} \mathrm{H}_{13} \mathrm{~N}_{2} \mathrm{O}_{3} \mathrm{~F}_{2}{ }^{11} \mathrm{BNa}: 341.0885$, found : 341.0884

\subsection{Crystallography}

Single-crystal diffraction data were collected on APEX II Bruker AXS diffractometer, Mo K $\alpha$ radiation $(\lambda=0.71073 \AA$ ), for compounds 5a, 5b, 7, 8a and 9a (Centre de Diffractométrie $X$, Université de Rennes, France). The structures were solved by direct methods using the SIR97 program, ${ }^{19}$ and then refined with full-matrix least-square methods based on F2 (SHELX-97) ${ }^{20}$ with the aid of the WINGX program. ${ }^{21}$ All non-hydrogen atoms were refined with anisotropic atomic displacement parameters. $\mathrm{H}$ atoms were finally included in their calculated positions. Crystal data for 5a: $\left(\mathrm{C}_{19} \mathrm{H}_{15} \mathrm{BF}_{2} \mathrm{FeO}_{4}\right)$; $\mathrm{M}=411.97$. $\mathrm{T}=294(2) \mathrm{K}$; monoclinic $\mathrm{P} 2_{1} / \mathrm{c}$, $a=11.323(5), b=10.313(7), c=15.246(9) \AA, \beta=103.71(3) \stackrel{\circ}{\circ} V=1729.6(17) \AA^{3}, Z=4, d=1.582$ g.cm ${ }^{-3}, \mu=0.915 \mathrm{~mm}^{-1}$. A final refinement on $F^{2}$ with 3903 unique intensities and 245 parameters converged at $\omega R\left(F^{2}\right)=0.1034(R(F)=0.0429)$ for 2554 observed reflections with $I>2 \sigma(I)$.

Crystal data for 5b: $\left(\mathrm{C}_{18} \mathrm{H}_{15} \mathrm{BF}_{2} \mathrm{O}_{4} \mathrm{~S}_{4}\right) ; \mathrm{M}=472.35$. $\mathrm{T}=150(2) \mathrm{K}$; monoclinic $\mathrm{P} 2_{1} / \mathrm{c}$, $a=14.6844(17), b=12.3494(15), c=11.3986(10) \AA, \beta=102.523(4) \circ, V=2017.9(4) \AA^{3}, Z=4$, $d=1.555$ g.cm ${ }^{-3}, \mu=0.512 \mathrm{~mm}^{-1}$. A final refinement on $F^{2}$ with 4584 unique intensities and 266 parameters converged at $\omega R\left(F^{2}\right)=0.1122(R(F)=0.0523)$ for 2425 observed reflections with $I>2 \sigma(I)$.

Crystal data for 7: $\left(\mathrm{C}_{8} \mathrm{H}_{10} \mathrm{~N}_{2} \mathrm{O}_{3}\right)$; $\mathrm{M}=182.18 \mathrm{~T}=100 \mathrm{~K}$; orthorhombic Pcnb, $a=7.5868$ (5), $b=14.5439$ (9), $c=14.8425(9) \AA, \alpha=\beta=\gamma=90.0 \circ, V=1637.75(18) \AA^{3}, Z=8, d=1.478$ g.cm ${ }^{-3}$, 
$\mu=0.115 \mathrm{~mm}^{-1}$. A final refinement on $F^{2}$ with 1870 unique intensities and 126 parameters converged at $\omega R\left(F^{2}\right)=0.1255(R(F)=0.0459)$ for 1520 observed reflections with $I>2 \sigma(I)$.

Crystal data for 8a: $\left(\mathrm{C}_{19} \mathrm{H}_{18} \mathrm{FeN}_{2} \mathrm{O}_{3}\right)$; $\mathrm{M}=378.2$. T=150(2) K; monoclinic P 2 $/$ c, $a=7.4264(3)$, $b=18.3887(8), c=12.2869(5) \AA, \beta=103.5250(10) \stackrel{\circ}{ }, V=1631.39(12) \AA^{3}, Z=4, d=1.54$ g.cm ${ }^{-3}$, $\mu=0.946 \mathrm{~mm}^{-1}$. A final refinement on $F^{2}$ with 3735 unique intensities and 231 parameters converged at $\omega R\left(F^{2}\right)=0.0642(R(F)=0.0258)$ for 3309 observed reflections with $I>2 \sigma(I)$.

Crystal data for 9a: $\left(\mathrm{C}_{19} \mathrm{H}_{17} \mathrm{BF}_{2} \mathrm{FeN}_{2} \mathrm{O}_{3}\right)$; $\mathrm{M}=426.01$. $\mathrm{T}=150$ (2) $\mathrm{K}$; monoclinic $\mathrm{P} 12_{1} / \mathrm{n}$, $a=7.0024(12), b=13.757(2), c=18.610(3) \AA, \beta=90.130(8){ }^{\circ}, V=1792.7(5) \AA^{3}, Z=4, d=1.578$ g. $\mathrm{cm}^{-3}, \mu=0.885 \mathrm{~mm}^{-1}$. A final refinement on $F^{2}$ with 4072 unique intensities and 256 parameters converged at $\omega R\left(F^{2}\right)=0.0953(R(F)=0.0477)$ for 2797 observed reflections with $I>2 \sigma(I)$.

\section{Supplementary data}

Crystallographic data for structural analysis have been deposited with the Cambridge Crystallographic Data Centre, CCDC No 1428516-1428520 for compounds 5a, 5b, 7, 8a and 9a respectively. Copies of this information may be obtained free of charge from The CCDC, 12 Union Rd, Cambridge CB2 1EZ, UK (fax: +44 1223 336033; e-mail: deposit@ccdc.cam.ac.uk or http://www.ccdc.cam.ac.uk).

\section{Acknowledgements}

This work was supported by the PHC Tassili 11 MDU 828.

\section{References}

1. Gupta, G. K.; Mittal, A.; Kumar, V. Lett. Org. Chem. 2014, 11, 273-286. 
2. Lorcy, D.; Bellec, N.; Fourmigué, M.; Avarvari, N. Coord. Chem. Rev. 2009, 253, 13981438.

3. (a) Casabó, J.; Marquet, J.; Moreno-Mañas, M.; Prior, M.; Teixidor, F.; Florencio, F.; Martínez-Carrera, S.; García-Blanco, S. Polyhedron 1987, 6, 1235-1238. (b) Luo, H.; Liu, S.; Rettig, S. J.; Orvig, C. Can. J. Chem. 1995, 73, 2272-2281. (c) Chalaça, M. Z.; FigueroaVillar, J. D.; Ellena, J. A.; Castellano, E. E. Inorg. Chim. Acta 2002, 328, 45-52. (d) Cindrić, M.; Vrdoljak, V.; Strukan, N.; Tepeš, P.; Novak, P.; Brbot-Saranović, A.; Giester, G.; Kamenar, B. Eur. J. Inorg. Chem. 2002, 2128-2137. (e) Hsieh, W.-Y. ; Zaleski. C. M.; Pecoraro, V. L.; Fanwick, P. E.; Liu. S. Inorg. Chim. Acta 2006, 359, 228-236. (f) Chitrapriya, N.; Mahalingam, V.; Zeller, M.; Jayabalan, R.; Swaminathan, K. Natarajan, K. Polyhedron 2008, 27, 939-946. (g) Djedouani, A.; Boufas, S.; Bendaas, A.; Allain, M.; Bouet, G. Acta Cryst. 2009, E65, m1205-m1206.

4. (a) Gupta, A. K.; Pal, R. World J. Pharm. Pharm Sciences 2015, 4, 386-425. (b) Gupta, A. K.; Pal, R. Beniwal, V. World J. Pharm. Pharm Sciences 2015, 4, 990-1008

5. Xia, M.; Wu, B.; Xiang, G. J. Fluorine Chem. 2008, 129, $402-408$.

6. (a) Pellon, P.; Brulé, E.; Bellec, N.; Chamontin, K.; Lorcy, D. J. Chem. Soc., Perkin Trans. 1, 2000, 4409-4412. (b) Bellec N.; Lorcy, D. Tetrahedron Lett. 2001, 42, 3189-3191. (c) Pellon, P.; Gachot, G.; Le Bris, J.; Marchin, S.; Carlier, R.; Lorcy, D. Inorg. Chem. 2003, 42, 2056-2060. (d) Massue, J.; Bellec, N.; Chopin, S.; Levillain, E.; Roisnel T.; Clérac, R.; Lorcy, D. Inorg. Chem. 2005, 44, 8740-8748. (e) Gachot, G.; Pellon, P.; Roisnel T.; Lorcy, D. Eur. J. Inorg. Chem. 2006, 2604-2611. (f) Bellec, N.; Massue, J.; Roisnel, T.; Lorcy, D. Inorg. Chem. Commun. 2007, 10, 1172-1176. (g) Guerro, M.; Pham, N. H., P., Massue, J.; Bellec, N.; Lorcy, D. Tetrahedron 2008, 64, 5285-5290. (h) Gachot, G.; Pellon, P.; Roisnel, T.; Lorcy, D. J. Organomet. Chem. 2009, 694, 2531-2535. (i) Bakhta, S.; Guerro, M.; Kolli, B.; Barrière, F.; Roisnel, T.; Lorcy, D. Tetrahedron Lett. 2010, 51, 4497-4500. (j) Huang, K. 
L.; Bellec, N.; Guerro, M.; Camerel, F.; Roisnel, T.; Lorcy, D. Tetrahedron 2011, 67, 87408746.

7. Special issue on "Molecular conductors" Batail, P. Ed. Chem. Rev. 2004, 104, 4887-5781.

8. van Staveren, D. R.; Metzler-Nolte, N. Chem. Rev. 2004, 104, 5931-5985.

9. Guerro, M.; Dam, T.U.; Bakhta, S.; Kolli, B.; Roisnel, T.; Lorcy, D. Tetrahedron 2011, 67, $3427-3433$

10. Bacardit, R.; Moreno-Maňas, M.; Pleixats, R. J. Heterocyclic Chem. 1982, 19, 157-160.

11. Bartle, K. D.; Edwards, R. L.; Jones, D. W.; Mir, I. J. Chem. Soc. C, 1967, 413-419.

12. (a) Manaev, A.V.; Tombov, K.V.; Traven, V.F. Russian J. Org. Chem. 2008, 44, 10541060. (b) Ramkumar, K.; Tombov, K.V.; Gundla R.; Manaev, A.V.; Yarovenko, V.; Traven, V.F.; Neamati, N. Bioorg. Med. Chem. 2008, 16, 8988-8998.

13. (a) Mahesh, V. K.; Gupta, R. S. Indian J. Chem. 1974, 12, 570-572. (b) Djerrari, B.; Essassi, E.; Fifani, J. Bull. Soc. Chim. Fr 1991, 521-524.

14. Amar, A.; Meghezzi, H.; Boucekkine, A.; Kaoua, R.; Kolli, B. C. R. Chimie 2010, 13, 553-560.

15. Guerro, M.; Roisnel, T.; Lorcy, D. Tetrahedron, 2009, 65, 6123-6127.

16. Olmsted, J. J. Phys. Chem. 1979, 83, 2581-2584.

17. Mei, J.; Hong, Y.; Lam, J. W. Y.; Qin, A.; Tang, Y.; Tang, B. Z. Adv. Mater. 2014, 26, $5429-5479$.

18. (a) Wang, S.; Xue, P.; Wang, P.; Yao, B. New J. Chem. 2015, 39, 6874-6881. (b) Würthner, F.; Kaiser, T. E.; Saha-Möller C. R. Angew. Chem. Int. Ed. 2011, 50, 3376-3410.

19. Altomare, A.; Burla, M. C.; Camalli, M.; Cascarano, G.; Giacovazzo, C.; Guagliardi, A.; Moliterni, A. G. G.; Polidori, G.; Spagna, R. J. Appl. Crystallogr. 1999, 32, 115-119.

20. Sheldrick, G. M. Acta Crystallogr. 2008, A64, 112-122

21. Farrugia, L. J. J. Appl. Crystallogr. 1999, 32, 837-838. 